\title{
Varietas Padi Lokal Jawa Timur Tahan Cekaman Kekeringan Berdasarkan Gen DREB2A
}

\author{
Yudrik Lathif ${ }^{1}$, Dwi Listyorini ${ }^{1,3)}$, Suharti ${ }^{2,3)^{*}}$ \\ ${ }^{1)}$ Jurusan Biologi, Fakultas Matematika dan Ilmu Pengetahuan Alam, Universitas Negeri Malang, Jl. Semarang 5 \\ Malang, Indonesia \\ ${ }^{2)}$ Jurusan Kimia, Fakultas Matematika dan Ilmu Pengetahuan Alam, Universitas Negeri Malang, Jl. Semarang 5 \\ Malang, Indonesia \\ ${ }^{3)}$ Laboratorium Sentral Mineral dan Material Maju, Fakultas Matematika dan Ilmu Pengetahuan Alam, \\ Universitas Negeri Malang, Jl. Semarang 5 Malang, Indonesia \\ ${ }^{*}$ Alamat Korespondensi: suharti.fmipa@um.ac.id
}

\begin{abstract}
ABSTRAK
Padi (Oryza sativa L.) adalah tanaman pangan utama masyarakat Indonesia. Masalah kekeringan dalam upaya penanaman padi adalah hal yang biasa di kalangan petani. Penelitian tahan cekaman kekeringan pada padi perlu dilakukan untuk mengatasi masalah ketersediaan pangan. Sifat tahan cekaman kekeringan pada tanaman salah satunya dikendalikan oleh gen $D R E B 2 A$. Varietas padi lokal Indonesia untuk tahan cekaman kekeringan belum banyak diteliti. Penelitian ini bertujuan untuk mempelajari varietas padi lokal Jawa Timur yang tahan terhadap cekaman kekeringan menggunakan, gen DREB2A, yang diisolasi menggunakan primer forward 5'-CCT CAT TGG GTC AGG AAG AA-3' dan primer reverse 5'-GGA TCT CAG CCA CCC ACT TA-3'. Penelitian ini menggunakan tiga varietas padi lokal, yaitu Berlian dan SOJ A3, keduanya dari Banyuwangi, dan varietas Jawa dari Malang. Isolasi DNA total dilakukan mengikuti protokol Kit Macherey-Nagel. Amplifikasi gen DREB2A dilakukan menggunakan metode Polymerase Chain Reaction (PCR). Fragmen gen DREB2A berhasil diamplifikasi sepanjang 239 bp (varietas Berlian), 239 bp (varietas SOJ A3), dan 240 bp (varietas Jawa). Analisis sampel gen $D R E B 2 A$ varietas padi lokal Jawa Timur menunjukkan hilangnya kemampuan gen $D R E B 2 A$ dari varietas Jawa untuk mengikat cis-regulator elemen promotor gen target.
\end{abstract}

Kata kunci: cekaman kekeringan, varietas padi lokal, Gen DREB2A, domain ERF/AP2

\section{East Java Local Rice Varieties Resistant to Drought Based on DREB2A Genes}

$$
\text { Yudrik Lathif }^{1)} \text {, Dwi Listyorini }{ }^{1,3)} \text {, Suharti }{ }^{2,3)^{*}}
$$

${ }^{1)}$ Department of Biology, Faculty of Mathematics and Natural Sciences, State University of Malang, Jl. Semarang 5

Malang, Indonesia

${ }^{2)}$ Department of Chemistry, Faculty of Mathematics and Natural Sciences, State University of Malang, Jl. Semarang 5 Malang, Indonesia

${ }^{3)}$ Central Laboratory of Mineral and Advanced Material, Faculty of Mathematics and Natural Sciences, State University of Malang, Jl. Semarang 5 Malang, Indonesia

${ }^{*}$ Email: suharti.fmipa@um.ac.id

\section{ABSTRACT}

Rice (Oryza sativa L.) $_{\text {. }}$ is a staple food for Indonesia people. The problem of drought is common among rice farmers. Drought-resistant rice needs to be developed to deal that problem. Droughtresistance in plants is controlled one of them by the $D R E B 2 A$ gene. So far, there is very limited study about this matter. This study was aimed to find local rice varieties that have drought-resistance using the $D R E B 2 A$ gene, which was isolated using a 5'-CCT CAT GG AGG AAG AA-3' forward primer and 5'-GGA TCT CAG CCA ACT CCC TA-3' reverse primer. Three local rice varieties, namely Berlian and SOJ A3, both were from Banyuwangi, and Jawa variety from Malang. Total DNA isolation was carried out following the protocol of Macherey-Nagel Kit. DREB2A gene amplification was carried out using the Polymerase Chain Reaction (PCR) method. The 239 bp (varieties of Berlian), 239 bp (varieties of SOJ A3), and 240 bp (varieties of Jawa) of $D R E B 2 A$ gene fragment were successfully amplified. 
Analysis of $D R E B 2 A$ gene samples of east Java local rice varieties, showing loss of ability of the $D R E B 2 A$ gene from Jawa varieties to bind cis-regulator elements target gene promoters.

Keywords: drought stress, local rice varieties, Gen $D R E B 2 A, \mathrm{ERF} / \mathrm{AP} 2$ domain

\section{PENDAHULUAN}

Padi (Oryza sativa L.) merupakan tanaman yang menghasilkan beras sebagai makanan pokok masyarakat Indonesia [1]. Pertumbuhan jumlah penduduk yang terus meningkat [2], menjadi tantangan pamerintah untuk mengembangkan bidang pertanian dalam menjamin ketersediaan pangan. Permasalahan umum bidang pertanian dalam penanaman padi adalah kekeringan [3], yang terjadi di beberapa daerah Indonesia [4] atau pada musim kemarau [3].

Indonesia memiliki berbagai macam varietas padi lokal yang belum banyak diteliti [5]. Penelitian varietas padi lokal Indonesia tentang tahan cekaman kekeringan penting dilakukan untuk mencari varietas padi yang berpotensi menghadapi tantangan pamerintah dalam menjamin ketersediaan pangan. Cekaman kekeringan pada tanaman salah satunya dikendalikan oleh gen DREB2 [6]. Homologi gen DREB2 pada padi adalah $D R E B 2 A$ [7]. Protein DREB2A adalah faktor transkripsi penting untuk mengatur banyak ekspresi gen responsif kekeringan [8]. Beberapa gen target DREB2A yaitu $M T 2 A$, Atlg69870, At3g53990, Atlg22985, RD29A, LEA14, At2g23120 [9], RD29B, At1g52690, RD17 [9][10], AtHsfA3, HSP18.2, dan Hsp70 [10].

Pentingnya gen DREB2A sebagai regulator berbagai macam gen responsif kekeringan, menjadikannya sebagai gen penanda tahan cekaman kekeringan. Penelitian ini menggunakan tiga varietas padi lokal asal Jawa timur, yaitu varietas Jawa dari kabupaten Malang, varietas Berlian dan SOJ A3 dari kabupaten Banyuwangi. Hasil penelitian ini diharapakan memberikan sumbangan informasi dalam mencari varietas padi lokal tahan cekaman kekeringan berdasarkan gen DREB2A.

\section{METODE PENELITIAN}

Isolasi DNA total. Isolasi DNA total dilakukan mengikuti protokol Macherey-Nagel Kit. Hasil isolasi DNA total diuji secara kuantitatif untuk melihat kemurnian dan konsentrasinya menggunakan Nanodrop. DNA total hasil isolasi digunakan sebagai template amplifikasi gen $D R E B 2 A$ menggunakan mesin Polymerase Chain Reaction (PCR). Amplifikasi gen DREB2A menggunakan primer forward 5'-CCT CAT TGG GTC AGG AAG AA-3 dan primer Reverse 5-GGA TCT CAG CCA CCC ACT TA-3' [11-12]. Proses amplifikasi dilakukan dengan suhu pradenaturasi $94^{\circ} \mathrm{C}$ selama 5 menit, diikuti 35 siklus, yaitu denaturasi $94^{\circ} \mathrm{C}$ selama 1 menit, kemudian annealing $59^{\circ} \mathrm{C}$ selama 2 menit dan extention $72^{\circ} \mathrm{C}$ selama 2 menit, serta extention untuk langkah terakhir pada $72^{\circ} \mathrm{C}$ selama 10 menit [12]. Keberhasilan proses amplifikasi di analisis dengan menggunakan elektroforesis. Gen DREB2A yang berhasil diamplifikasi dikirim ke $1^{\text {st }}$ Base Malaysia untuk proses sekuensing.

Analisis data sekuen. Analisis data sekuen hasil sekuensing dimulai dengan membaca dan editing sekuen gen DREB2A sampel varietas padi lokal Jawa Timur, menggunakan program aplikasi FinchTV dan BioEdit. Sekuen konsensus dibuat dengan menggabungkan sekuen forward dan reverse sampel menggunakan program aplikasi DNAbaser. Konfirmasi sekuen DREB2A hasil isolasi dilakukan dengan menggunakan program BLAST (https://blast.ncbi.nlm.nih.gov/Blast.cgi) untuk menyocokkan homologi sekuen sampel hasil isolasi dengan database di Genbank. Analisis dilanjutkan dengan alignment sekuen sampel dengan sekuen pembanding yang diperoleh dari hasil BLAST menggunakan program aplikasi ClustalX.

Analisis gen DREB2A. Analisis gen $D R E B 2 A$ diawali dengan menerjemahkan sekuen nukleotida sampel varietas padi lokal Jawa Timur dan sekuen nukleotida pembanding menjadi sekuen protein DREB2A menggunakan aplikasi BioEdit. Sekuen protein DREB2A sampel dan pembanding dianalisis menggunakan program Phyre2 (http://www.sbg.bio.ic.ac.uk/phyre2) untuk 
memperoleh informasi protein sampel dan pembanding. File PDB yang juga diperoleh dari hasil analisis program Phyre2 digunakan untuk analisis in silico menggunakan aplikasi PyMOL. Analisis in silico dilakukan dengan melihat posisi protein DREB2A sampel varietas padi lokal Jawa Timur terhadap pembandingnya yang menggunakan sekuen utuh protein DREB2A. Analisis in silico juga dilakukan dengan melihat hubungan fragmen protein DREB2A sampel terhadap promotor gen target responsif kekeringan yaitu DRE.

\section{HASIL DAN PEMBAHASAN}

Isolasi DNA total. Isolasi DNA total varietas padi lokal Jawa Timur telah berhasil dilakukan. Hasil isolasi DNA total divisualisasikan menggunakan elektroforesis (Gambar 1). Berdasarkan hasil visualisasi elektroforesis diketahui panjang gen DREB2A \pm 250 bp. Hasil isolasi DNA total digunakan sebagai template amplifikasi gen DREB2A.

Analisis data hasil sekuensing. Data hasil sekuensing gen $D R E B 2 A$ varietas padi lokal Jawa Timur didapatkan dengan panjang sekuen gen $D R E B 2 A$ varietas Berlian 239 bp, varietas SOJ A3 239 bp, dan varietas Jawa 240 bp. Berdasarkan hasil analisis program BLAST, diketahui sekuen yang diisolasi sudah benar (Tabel 1; Tabel 2). Analisis program BLAST menunjukkan sekuen hasil isolasi adalah gen DREB2A. Analisis program BLAST memperlihatkan sekuen hasil isolasi hanya mencakup $28 \%$ gen $D R E B 2 A$ dengan kecocokan sekuen sampel dengan sekuen database NCBI sebesar 97\%-98\%.

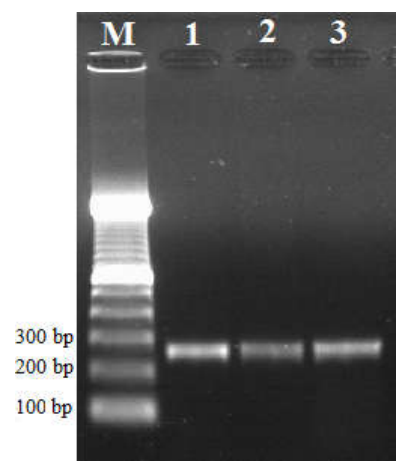

Gambar 1. Elektrogam gen $D R E B 2 A$ hasil PCR varietas padi lokal Jawa Timur. $\mathrm{M}=$ Marker $100 \mathrm{bp}$ plus DNA ladder; $1=$ Varietas Berlian; 2 = Varietas SOJ A3; 3 $=$ Varietas Jawa.
Alignment sekuen sampel varietas padi lokal Jawa Timur dilakukan dengan pembanding yang sudah diketahui sifat tahan cekaman kekeringannya, yaitu Oryza sativa Indica cv FL-478 DREB2A (KU159744) [13] dan Oryza sativa Indica cv Pokkali DREB2A (KU159743) [14] (Gambar 2). Berdasarkan hasil alignment diketahui sekuen hasil isolasi merupakan fragmen dari gen DREB2A. Panjang sekuen sampel hasil isolasi berada pada urutan ke 54-296 bp. Hasil alignment menunjukkan terjadinya mutasi pada fragmen gen $D R E B 2 A$ sampel varietas padi lokal Jawa Timur.

Mutasi yang terjadi berupa substitusi dan delesi. Subtitusi dapat diamati dari perbedaan urutan basa nukleotida [15], yang terjadi pada basa ke-54 (Berlian, SOJ A3 dan Jawa), basa ke-100 (SOJ A3), basa ke-255 (Berlian), basa ke-256 (Berlian, SOJ A3 dan Jawa), basa ke-257 (Berlian, SOJ A3 dan Jawa), basa ke-260 (SOJ A3 dan Jawa), dan basa ke-296 (Berlian, SOJ A3 dan Jawa). Adanya gap menunjukkan delesi basa nukleotida [16], yang terjadi pada basa ke-99 (SOJ A3), basa ke-109 (Berlian, SOJ A3 dan Jawa), basa ke-116 (Berlian, SOJ A3 dan Jawa), basa ke-116 (Berlian, SOJ A3 dan Jawa), basa ke-241 (Berlian), dan basa ke-247 (Berlian, SOJ A3 dan Jawa).

Tabel 1. Hasil analisis BLAST gen DREB2A varietas padi lokal Jawa Timur dengan Oryza sativa Indica cv FL478 DREB2A (KU159744).

\begin{tabular}{cccccc}
\hline Sampel & $\begin{array}{c}\text { Max } \\
\text { score }\end{array}$ & $\begin{array}{c}\text { Total } \\
\text { score }\end{array}$ & $\begin{array}{c}\text { Query } \\
\text { cover }\end{array}$ & E value & Ident. \\
\hline Berlian & 403 & 403 & $28 \%$ & $6 \mathrm{e}-117$ & $97 \%$ \\
SOJ A3 & 398 & 398 & $28 \%$ & $3 \mathrm{e}-115$ & $97 \%$ \\
Jawa & 409 & 409 & $28 \%$ & $1 \mathrm{e}-118$ & $98 \%$ \\
\hline
\end{tabular}

Tabel 2. Hasil analisis BLAST gen DREB2A varietas padi lokal Jawa Timur dengan Oryza sativa Indica cv Pokkali DREB2A (KU159743).

\begin{tabular}{cccccc}
\hline Sampel & $\begin{array}{c}\text { Max } \\
\text { score }\end{array}$ & $\begin{array}{c}\text { Total } \\
\text { score }\end{array}$ & $\begin{array}{c}\text { Query } \\
\text { cover }\end{array}$ & Evalue & Ident. \\
\hline Berlian & 403 & 403 & $28 \%$ & $6 \mathrm{e}-117$ & $97 \%$ \\
SOJ A3 & 398 & 398 & $28 \%$ & $3 \mathrm{e}-115$ & $97 \%$ \\
Jawa & 409 & 409 & $28 \%$ & $1 \mathrm{e}-118$ & $98 \%$ \\
\hline
\end{tabular}




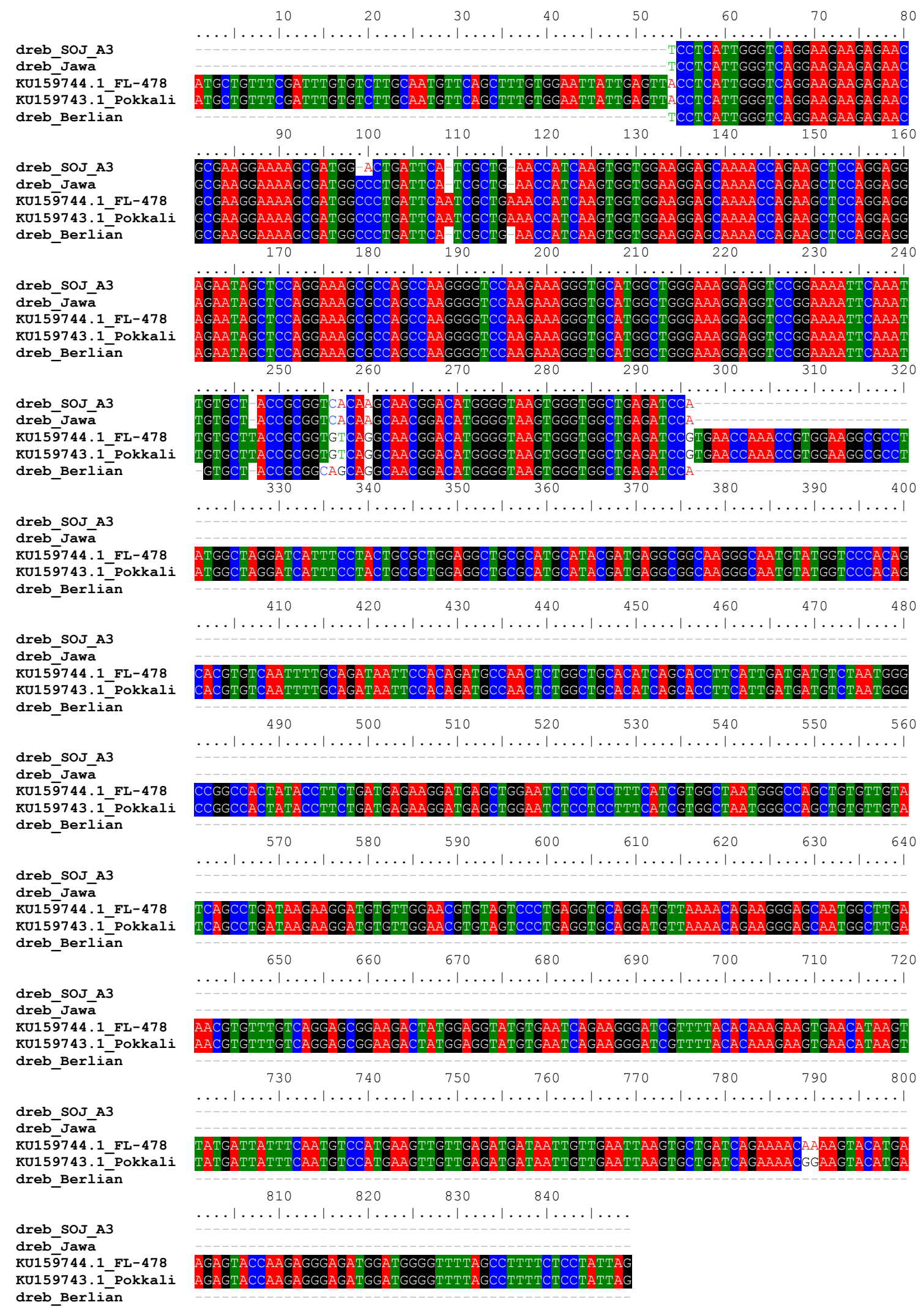

Gambar 2. Alignment sampel varietas padi Jawa Timur dan rujukan cv FL-478 dan cv Pokkali. 
Analisis gen DREB2A. Hasil analisis fragmen gen $D R E B 2 A$ yang diisolasi dari varietas Berlian dan SOJ A3 adalah ethylene responsive transcription factor (ERF096), yang merupakan subfamili dari domain Ehylene Responsive Factor/APETALA2 (ERF/AP2) [17]. Berbeda dengan varietas Jawa, hasil analisis fragmen yang diperoleh adalah protein translasi dari keluarga rL3. Domain ERF/AP2 merupakan bagian dari gen DREB2A [13]. Domain ERF/AP2 berfungsi mengikat elemen cis-regulator untuk promotor gen target, seperti GCC-box dan DRE/CRT [18]. Analisis secara in silico (Gambar 3; Gambar 4), menunjukkan hubungan fragmen varietas Berlian dan SOJ A3 dengan protein DREB2A pembanding, sedangkan fragmen varietas Jawa terpisah dengan protein DREB2A pembanding. Analisis in silico (Gambar 5) dilanjutkan dengan melihat hubungan fragmen protein sampel tehadap promotor gen target responsif kekeringan, yaitu DRE. Perbedaan hasil analisis fragmen protein DREB2A varietas Jawa menjadi protein translasi dari keluarga rL3, memperlihatkan hilangnya kemampuan gen DREB2A varietas Jawa, untuk mengikat elemen cis-regulator promotor gen target.

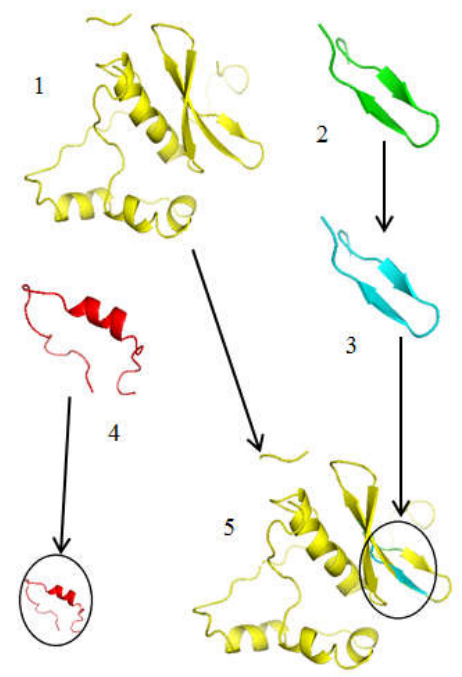

Gambar 3. Analisis in silico fragmen protein DREB2A varietas padi lokal Jawa Timur. 1 = Rujukan gen $D R E B 2 A$ $O$ sativa indica cv FL-478 (KU159744); $2=$ Varietas Berlian; 3 = Varietas SOJ A3; $4=$ Varietas Jawa; 5 = Penggabungan fragmen protein sampel dengan rujukan.

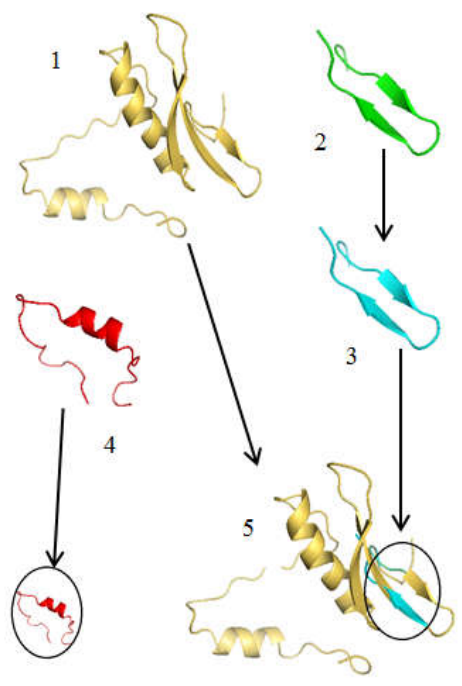

Gambar 4. Analisis in silico fragmen protein DREB2A varietas padi lokal Jawa Timur. 1 = Rujukan gen $D R E B 2 A$ $O$. sativa indica cv Pokkali $(\mathrm{KU} 159743) ; 2=$ Varietas Berlian; 3 = Varietas SOJ A3; $4=$ Varietas Jawa; 5 = Penggabungan fragmen protein sampel dengan rujukan. 


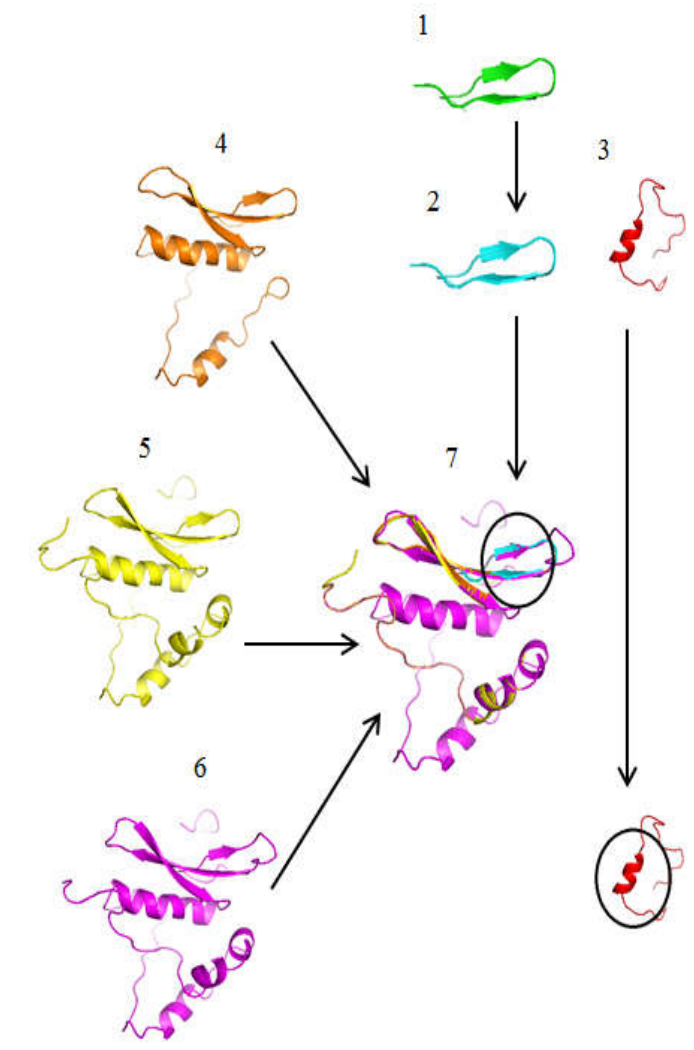

Gambar 5. Analisis in silico fragmen protein DREB2A varietas padi lokal Jawa Timur. 1 = Varietas Berlian; 2 = Varietas SOJ; 3 = Varietas Jawa; $4=$ Rujukan gen DREB2A O. sativa indica cv Pokkali (KU159743); 5 = Rujukan gen DREB2A O. sativa indica cv FL478 (KU159744); $6=$ Rujukan DRE O. sativa (AFM74032); $7=$ Penggabungan fragmen protein sampel dan protein DREB2A pembanding, dengan promotor gen target responsive kekeringan DRE.

\section{KESIMPULAN}

Berdasarkan hasil alignment sekuen gen DREB2A sampel varietas padi lokal Jawa Timur dengan Oryza sativa cv FL-478 dan cv Pokkali diketahui sekuen hasil isolasi hanya berupa fragmen gen $D R E B 2 A$. Fragmen gen $D R E B 2 A$ yang diperoleh memperlihatkan mutasi yang terjadi. Berdasarkan hasil analisis program Phyre2 dan in silico, sampel varietas Jawa memperlihatkan kehilangan kemampuan gen $D R E B 2 A$ yang dimiliki untuk mengikat elemen cis-regulator promotor gen target.

\section{UCAPAN TERIMA KASIH}

Ucapan terimakasih kepada bapak Mahrus Ismail, asisten laboratorium genetika Universitas Islam Negeri Maulana Malik Ibrahim Malang, yang membantu penelitian ini. Bapak Abdullah Fuad untuk fasilitas di laboratorium Pusat Bioteknologi Mineral dan Material Maju FMIPA Univesitas Negeri Malang. Penelitian ini didanai oleh proyek 4 in 1 IDB dan proyek DRPM Dikti melalui D.L dan S.

\section{DAFTAR PUSTAKA}

[1] Noviasari S, Kusnandar F, Setiyono A, Budijan (2017) Physical, chemical, and sensory characteristics of rice analogue from non rice ingredients. Jurnal Pangan 26: 1-11.

[2] Badan Pusat Statistik Indonesia, Badan Pusat Statistik Indonesia (2013) Proyeksi penduduk indonesia indonesia population projection 2010-2035. Badan Pusat Statistik Indonesia Hal. 978-979.

[3] Suciantini S (2017) Analisis risiko kekeringan dengan menggunakan decision network di sentra produksi padi di Jawa Barat. Biodiversitas 3:62-68.

[4] Hafif B (2016) Optimasi potensi lahan kering untuk pencapaian target peningkatan produksi padi satu juta ton di Provinsi Lampung. Jurnal Penelitian dan Pengembangan Pertanian 35(2): 8188.

[5] Sitaresmi T, Wening RH, Rakhmi AT, Yunani N, Susanto U (2013) Pemanfaatan plasma nutfah padi varietas lokal dalam perakitan varietas unggul. IPTEK Tanaman Pangan 8(1): 22-30.

[6] Akhtar M, Jaiswal A, Taj G, Jaiswal JP, Qureshi MI, Singh NK (2012) DREB1/CBF transcription factors: their structure, function and role in abiotic stress tolerance in plants. Journal of Genetics 91(3): 385-95.

[7] Sakuma Y, Liu Q, Dubouzet JG, Abe H, Yamaguchi-Shinozaki K, Shinozaki K (2002) DNA-binding specificity of the ERF/AP2 domain of Arabidopsis DREBs, transcription factors involved in dehydration- and cold-inducible gene expression. Biochemical and Biophysical Research Communication 
290(3): 998-1009.

[8] Fujita Y, Yoshida T, YamaguchiShinozaki K (2013) Privotal role of the AREB/ABF-SnRK2 pathway in abremediated transcriptional in response to osmotic stress in plants. Physiologia Plantarum 147(1): 15-27.

[9] Sakuma Y, Maruyama K, Osakabe Y, Qin F, Seki M, Shinozaki K, Yamaguchi-Shinozaki K (2006) Functional analysis of an arabidopsis transcription factor, DREB2A, involved in drought-responsive gene expression. Plant Cell 18(5): 1292-1309.

[10] Qin F, Shinozaki K, YamaguchiShinozaki K (2011) Achievements and challenges in understanding plant abiotic stress responses and tolerance. Plant Cell Physiology 52(9): 1569-82.

[11] Kumar S (2016) Identification of DREB and SSR linked drought sequences in finger millet (Eleusine coracana L.) Gaertn.) genotypes. Master Thesis. College Of Biotechnology Birsa Agricultural University, Ranchi, India.

[12] Jadhao KR, Samal KC, Pradhan SK, Rout GR (2014) Studies on Molecular Characterization of DREB Gene in Indica Rice (Oryza sativa L.). Hereditary Genetics 3(3): 1-12. doi:10.4172/2161-1041.1000133.

[13] Oh S-J, Kim YS, Kwon C-W, Park HK, Jeong JS, Kim J-K (2009) Overexpression of the transcription factor AP37 in rice improves grain yield under drought conditions. Plant Physiology 150(3): 1368-1379.

[14] de Silva WSI, Perera MMN, Perera KLNS, Wickramasuriya AM, Jayasekera GAU (2017) In silico Analysis of osr $40 \mathrm{c} 1$ promoter sequence isolated from Indica variety Pokkali. Rice Science 24(4): 228-234.

[15] Porceddu A, Camiolo S (2017) Patterns of spontaneous nucleotide substitutions in grape processed pseudogenes. Diversity 9(4): $45 . \quad$ doi: 10.3390/d9040045.

[16] Capella-Gutiérrez S, Gabaldón T (2013) Measuring guide-tree dependency of inferred gaps in progressive aligners. Bioinformatics 29(8): 1011-1017.

[17] Wang X, Hou C, Zheng K, Li Q, Chen S, Wang S (2017) Overexpression of ERF96, a small ethylene response factor gene, enhances salt tolerance in Arabidopsis. Biologia Plantarum 61(4): 693-701. doi: 10.1007/s10535-0170734-7.

[18] Gu C, Guo ZH, Hao PP, Wang GM, Jin ZM, Zhang SL (2017) Multiple regulatory roles of AP2/ERF transcription factor in angiosperm. Botany Studies 58(1):1-8. 